\title{
Preliminary investigation of the 20 August 2014 debris flows triggered by a severe rainstorm in Hiroshima City, Japan
}

\author{
Fawu Wang ${ }^{1,2^{*}}$, Ying-Hsin $\mathrm{Wu}^{2}$, Hufeng Yang ${ }^{1}$, Yuta Tanida $^{1}$ and Atsushi Kamei ${ }^{1}$
}

\begin{abstract}
Background: In the early morning of 20 August 2014, a high-intensity/low-duration rainstorm occurred in Hiroshima City, in southwest Japan. Within $3 \mathrm{~h}$, the rainfall exceeded $200 \mathrm{~mm}$, which is more than twice the monthly-average for this area. This heavy rainfall triggered 107 debris flows and 59 shallow slides, which caused 44 injuries, and 74 deaths. 133 houses were destroyed and an additional 296 houses were severely damaged. Most of the debris flows occurred in heavily weathered granite slopes, while others occurred in weathered hornfels slopes. A field investigation on two of the gullies in which the debris flows occurred was conducted in order to better understand the characteristics of the debris flows.

Results: The main purpose of this investigation was to understand the geomorphological and geological conditions, the soil properties, and the initiation/traveling mechanisms of the debris flows. The longitudinal and cross-sectional profiles along the two gullies were measured, beginning at the source areas and ending at the downstream limits of the deposition areas. For soil property determination, disturbed and undisturbed soil samples were collected for laboratory tests which included in-situ density measurement, grain size distribution analysis and triaxial compression tests. In the triaxial compression tests, consolidated-undrained compression tests under different confining stresses were conducted to measure the strength parameters of the strongly-weathered granite. Pore-water pressure controlled triaxial test was conducted to simulate the failure process of the slope given an increase of the pore-water pressure. Chemical analyses of the granite samples were also conducted in order to understand the degree of weathering of the granite in the debris flow gully.

Conclusions: A high intensity, short duration, localized rainfall event initiated debris flows in very steep slopes. These were initiated as a thin sliding mass in weathered coarse-grained granite and hornfels, and became two different types of debris flow after traveling down the slopes. The slope angle and the cross section of the gully, and the grain size of the debris significantly controlled the motion behavior of the debris flows.
\end{abstract}

Keywords: Hiroshima; Heavy rainfall; Debris flow; Granite; Hornfels; Investigation

\section{Background}

In the early morning of 20 August 2014, a high-intensity/ short-duration, localized rainfall event triggered many shallow slides and debris flows in the Asakita and Asaminami Wards in the northern part of Hiroshima City, Japan. In all, there were 166 slope failures triggered by the heavy rainfall event, including 107 debris flows and 59 shallow slides, which caused 44 injuries

\footnotetext{
* Correspondence: wangfw@riko.shimane-u.ac.jp

${ }^{1}$ Department of Geoscience, Shimane University, Matsue 690-8504, Japan

${ }^{2}$ Project Center on Natural Disaster Reduction, Shimane University, Matsue 690-8504, Japan
}

(c) 2015 Wang et al. This is an Open Access article distributed under the terms of the Creative Commons Attribution License (http://creativecommons.org/licenses/by/4.0), which permits unrestricted use, distribution, and reproduction in any medium, provided the original work is properly credited.

and 74 deaths. In addition, 133 houses were destroyed and 296 houses were severely damaged (Ministry of Land, Infrastructure, Transport and Tourism 2014; Yamamoto and Kobayashi 2014). Shallow slides were designated as those that moved for a limited distance from the source area. Most of the loss of life and property was caused by debris flows. In this paper, all of the slope failures are called debris flows for simplification. Figure 1 illustrates the distribution of debris flows and fatalities. As indicated, the debris flows were distributed in an elongated area extending northeast to southwest and covering the Asaminami Ward and Asakita Ward.

\section{Springer}




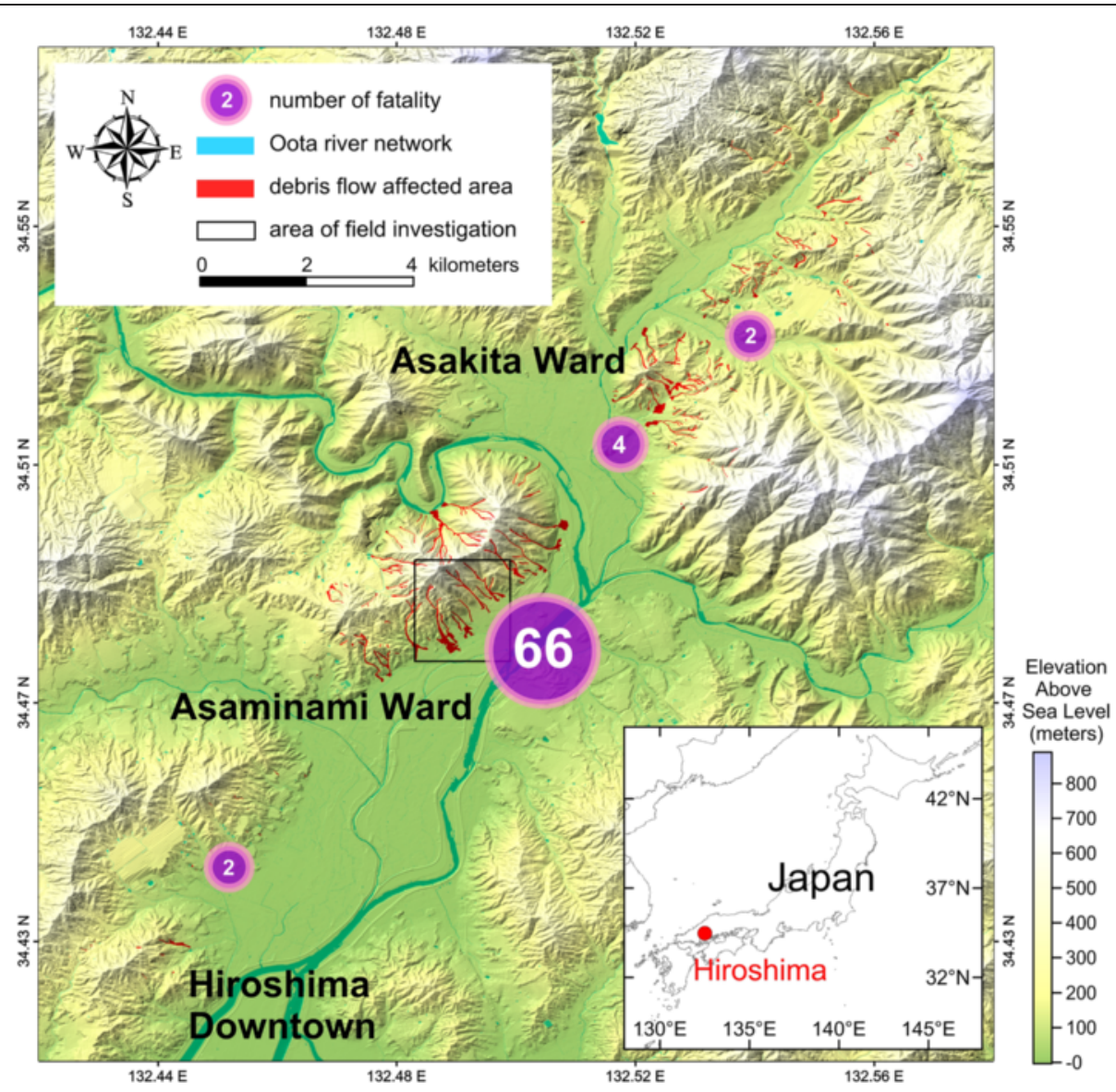

Fig. 1 Distribution of debris flows and landslide-affected area and number of fatalities. The longitude and latitude is in the decimal format in the all figures hereafter. The debris-flow distribution and fatality number are obtained from Ministry of Land, Infrastructure, Transport and Tourism. DEM data is from Geospatial Information Authority of Japan (GSI). The black rectangle indicates the study area (see Fig. 4 for more detailed aerial photograph)

Most of the fatalities were concentrated in the Asaminami Ward (Asa is the name of the region; Asaminami means Southern Asa, while Asakita means Northern Asa, in Japanese).

In past decades, many landslide and debris flow events have been triggered by high intensity, short-duration rainstorms, and caused loss of life and infrastructure damage worldwide (e.g. García-Martínez and López 2005; Casagli et al. 2006; Tang et al. 2012; Cevaso et al. 2014; Chen et al. 2014; Ni et al. 2014; Yang et al. 2015). For example, in December 1999, extreme rainfall on the northern Venezuelan coast triggered a disastrous debris flow, which caused about 1,500 fatalities and the destruction of 23,000 houses (García-Martínez and López 2005). Recently, Japan also suffered from many disasters triggered by extreme rainfall. In September 2011, Typhoon 12 (Talas) attacked the Kii peninsula of central Japan and triggered many landslides and floods, causing 97 casualties (Saito and Matsuyama 2012). Then in July 2012, an unprecedented four-day heavy rainfall hit Kyushu in
Southwest Japan and formed devastating floods and mudslides, and was associated with 32 people who were reported either dead or missing; 400,000 people were evacuated from their homes (Duan et al. 2014). Disasters triggered by extreme-rainfall have become a critical and urgent issue for society.

In the Hiroshima area, the 2014 events were preceded by other catastrophic sediment disasters in recent years. At the end of June 1999, 139 debris flows and 186 shallow slides were triggered by rainfall, and caused 32 deaths in a nearby area (The Chugoku Shimbun Online 1999; Wang et al. 2003). Mainly because of this disaster, a law referred to as the "Sediment Disaster Countermeasures for Sediment Disaster Prone Areas Act" was enacted in 2000 to prevent sediment problems caused by debris flows and other causes. Despite the protection of the law for the previous 14 years, the loss of life caused by debris-flow sediment disasters triggered by one heavy rainfall event was not prevented; indeed the loss of life in the 2014 events was almost three times 
that in 1999. These events brought a huge amount of distress, and severely impacted the local community. The public as well as the academic community, are extremely interested in the causes of the disaster and desire to know the triggering factors and field conditions. Many methodologies have been developed and applied to this topic. To reveal the disaster impact in a larger area, statistical analysis is applied to analyze landslide susceptibility in terms of slope inclination, land use, and other factors (e.g., Lepore et al. 2012; Tang et al. 2012; Winter et al. 2013; Cevaso et al. 2014; Chen et al. 2014; Dijkstra et al. 2014). On the other hand, for a localized catchment, the physically-based models, e.g., slope stability analysis and hydrological models, (e.g., Casagli et al. 2006; Tsuchida et al. 2014) or field monitoring and laboratory tests (e.g., Montgomery et al. 2009; Okada and Kurokawa 2015) are used to analyze the initiation mechanism of shallow landslides or mudslides under different rainfall conditions. In order to assess the future risks in the disaster area, field survey and laboratory tests for the analyses of geological and geomorphological conditions, and soil properties are considered in this paper. Therefore, we shall report the hazard background briefly as well as the results of the field survey and laboratory analysis of soil mechanical and geochemical properties. As shown with a black rectangle in Fig. 1, our investigation focuses on two debris flows in the Asaminami Ward, which suffered major life loss due to its higher population density on the narrow alluvial plain, compared to the Asakita Ward.

The main triggering factor of the debris flows was the high intensity and short duration rainstorm. Figure 2 illustrates the isohyetal map of the cumulative rainfall for $48 \mathrm{~h}$ on 19 and 20 August 2014. It shows that most

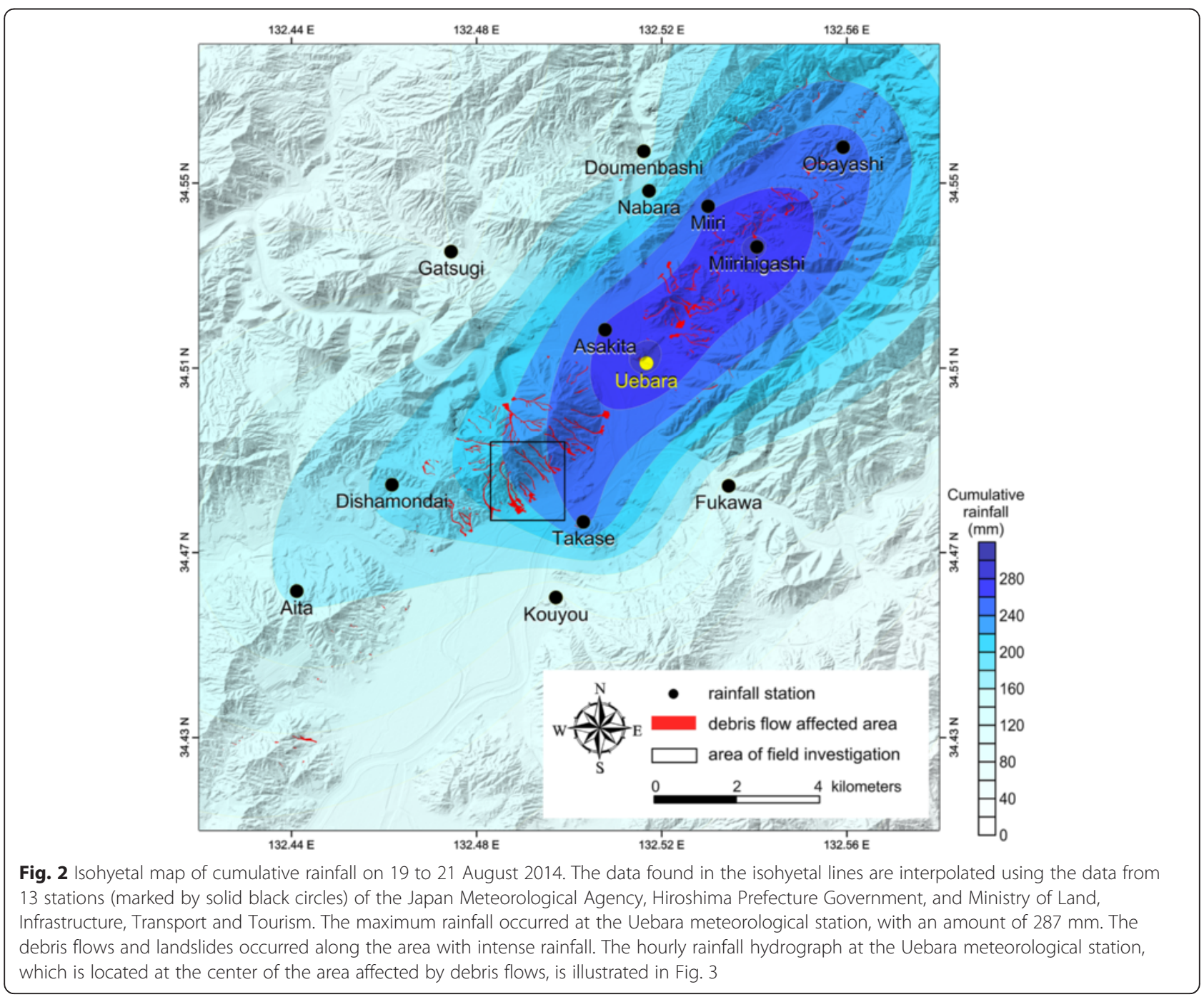


of debris flows occurred in the area of intense rainfall, of which the cumulative rainfall is greater than $200 \mathrm{~mm}$. The maximum rainfall was recorded at the Uebara meteorological station, with an amount of $287 \mathrm{~mm}$, and the recorded maximum in 2 days during the disaster is almost 2.6 times the August monthly-average value of $110.8 \mathrm{~mm}$ in Hiroshima (Japan Meteorological Agency 2015). Figure 3 shows the hourly rainfall hydrograph at the Uebara meteorological station. The maximum threehour rainfall is $236 \mathrm{~mm}$ from 2:00 to 5:00 a.m. (local time) on 20 August. In particular, the maximum hourly rainfall is $115 \mathrm{~mm}$ at 4:00 a.m. on the same day. Witnesses verified that the debris flows occurred around 4:00 a.m. on the same day (The Japan Times 2014). We conclude that this unusual and extreme rainfall is the main triggering factor of these events.

Figure 4 illustrates the geology of the affected area. Debris flows were distributed in an area $10 \mathrm{~km}$ by $2 \mathrm{~km}$, extending in a NE-SW direction. The elevation in this area reaches $700 \mathrm{~m}$. A valley, which is controlled by a NE-SW fault, trends through this area. Late Cretaceous granite, also called Hiroshima granite, is the main bedrock in this mountainous region. In the valley and lower slopes, deposits of weathered granite are encountered. In the area of Hiroshima granite, coarse granite is mainly distributed in the middle and lower slopes of the mountain, and fine granite overlies the coarse granite. Generally, the grain size in fine granite is around $1 \mathrm{~mm}$, and in coarse granite is several $\mathrm{mm}$ (Takahashi 2014). In some places, hornfels overlays the coarse granite. Hornfels is a contact metamorphic rock. It is formed when sandstone and shale are indurated and transformed by the heat of intrusive granite. Relatively, the fine granite and hornfels are much more resistant to weathering than coarse granite. As a result, the slopes in fine granite and hornfels are generally steeper than those in coarse granite. The coarse Hiroshima granite is very easily weathered. The granitic soil (i.e., the residual soil) is locally called Masado, which means "real sand" in Japanese. Because of the intense wreathing, the Masa-do can easily lose its structure and collapse during heavy rainfall.

In this study, we investigated two gullies in which the greatest number of fatalities occurred, called Midori-gaoka and Abu-no-sato, respectively (see Fig. 5 for the affected areas and positions). Both of the debris flows originated from similar elevations and can be categorized as channelized, but their affected areas are quite different. The Midori-ga-oka debris flow entered the residential area and persisted over a long distance while also spreading to cover a wide area. This phenomenon can also be observed in (Fig. 6a). However, the Abu-nosato debris flow stopped behind the residential area (Fig. 6b). The different travel distances may imply different mobility rates of the debris flows. Understanding the factors causing the different mobility may be helpful for disaster reduction. For this reason, we selected these two debris flows for detailed study.

In the field investigation, observation of the geological conditions, measurement of the longitudinal and crosssectional profiles, and the collection of soil samples in source and deposition areas were the main objectives. The deposits in the debris flow gullies were also observed. In the geomorphological analysis, we discuss the effect of topography not only along the longitudinal section, but also the cross section. To clarify the initiation mechanism of the debris flows, we discuss the failure process of a granitic soil slope under increased pore water pressure caused by heavy rainfall through a simulation test with triaxial compression equipment. However, as there is an absence of data from the two gullies before the disaster, the entrainment or erosion processes cannot be analyzed in this study. Instead, we only focus

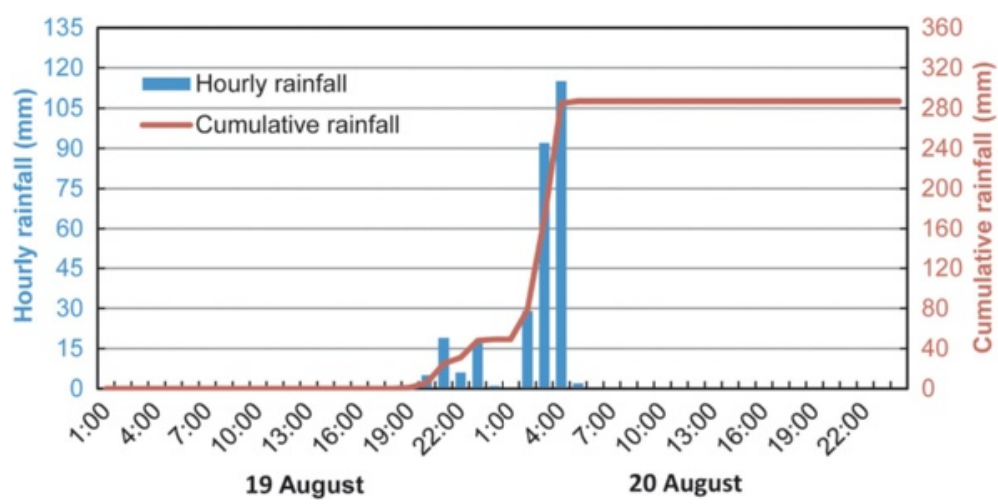

Fig. 3 Hourly rainfall at the Uebara meteorological station on 19 and 20 August 2014. The cumulative rainfall is 287.0 mm. The maximum hourly rainfall is $115.0 \mathrm{~mm}$ at 4:00 a.m. (local time) on 20 August 2014. The maximum three-hour rainfall is $236.0 \mathrm{~mm}$ from 2:00 to 5:00 a.m. on 20 August 2014 (Data source: Hiroshima Prefecture, 2014) 


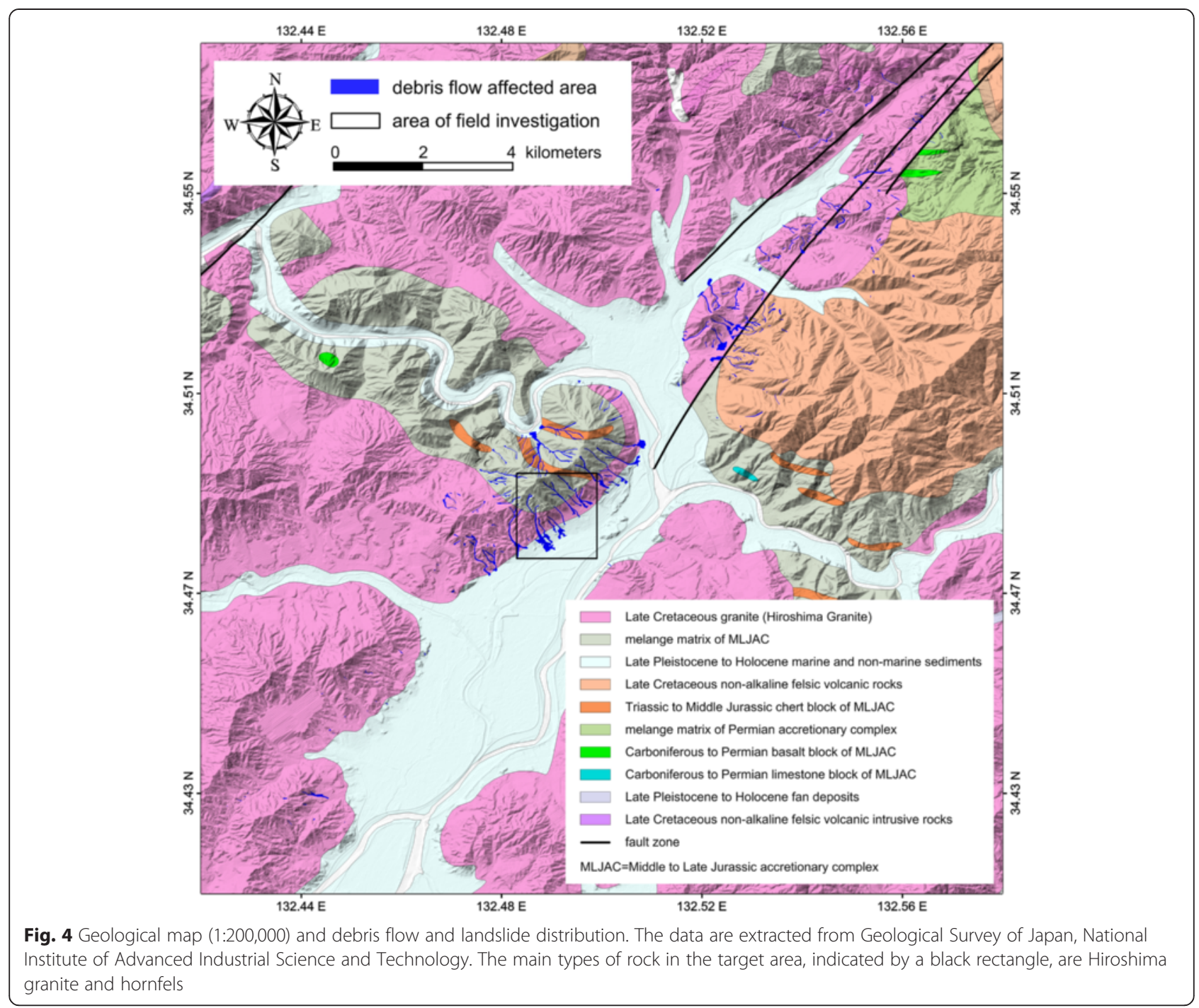

on the initiation mechanism of shallow slides in the source area.

\section{Methods \\ Longitudinal and cross section measurement of the debris flow gullies}

We investigated the two gullies of Midori-ga-oka debris flow and Abu-no-sato debris flow from the source areas to the downstream limits of the run-out zones (see Fig. 5 for details). Along the whole gully, we measured the longitudinal and cross-sectional profiles at every cliff and slope using laser rangers, ranging rods, inclinometers and GPS trackers. The locations for measurement are marked by solid cyan circles in Fig. 5. At each point, the label was assigned an " $\mathrm{S}$ " for a slope or " $\mathrm{C}$ " for a cliff, and followed by a sequential number from upstream to downstream in ascending order. The source areas were investigated in more detail. The deposit profile is also shown in the longitudinal sections.

\section{Sampling and mechanical property analysis of soils}

During the field survey, we collected undisturbed and disturbed soil samples in both gullies (see Fig. 5 for sampling locations). In the Midori-ga-oka debris flow, three undisturbed samples (Nos. 1 and 2 in the left source area, and No. 3 in the right source area) were collected for the analysis of physical parameters and the mechanical properties of the soil. At the location of sample No. 3, a disturbed soil sample (labeled as No. 3-DIS) was also collected for the analysis of the initiation mechanism, for use with triaxial tests. In the deposition area of the two gullies, three samples (Nos. 4, 5, and 6) were collected for grain size analysis and permeability characterization. Finally, the fresh granite, the weathered granite, and the granitic soil were also 


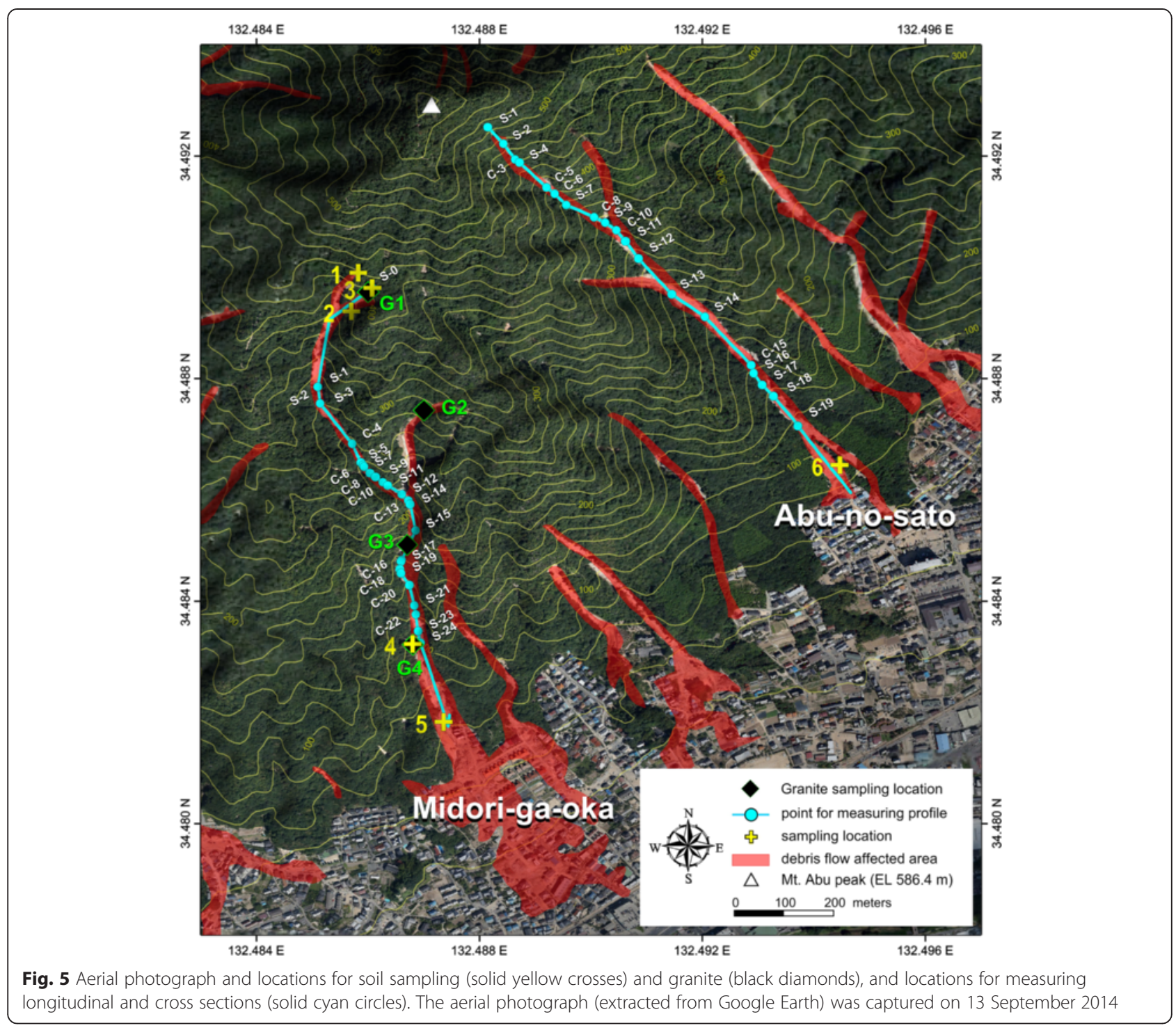

collected in the Midori-ga-oka gully for the geochemical analysis. The sample locations are shown in Fig. 5.

\section{Geochemical analysis of the granite sample}

Major element compositions of the fresh granite, the weathered granite, and the granitic soil were determined using a Rigaku RIX-2000 X-ray fluorescence spectrometer (XRF). The samples were crushed manually in an iron mortar. The rock chips were then grounded in an agate mortar crusher for $30 \mathrm{~min}$. All analyses by XRF were made on glass beads prepared in an automatic bead sampler, using an alkali flux comprising $80 \%$ lithium tetraborate and $20 \%$ lithium metaborate, with a sample to flux ratio of 1:2. The Analytical procedure is described by Kimura and Yamada (1996).

\section{Consolidated-undrained triaxial compression tests}

With sample No. 3-DIS, the consolidated undrained triaxial tests were conducted to measure the effective soil strength parameters. Dry soil passing $2 \mathrm{~mm}$ sieving was used to make a cylindrical specimen, and the dry density was adjusted to the same value as the in-situ dry density of the soil. After that, the specimen was fully saturated.

With the fully saturated specimens, three consolidated-undrained compression tests were conducted under three different confining stresses (50, 75 and 100 $\mathrm{kPa}$ ). After normal consolidation, the specimen was compressed at $1.0 \%$ axial strain per minute under undrained conditions. Through the tests, the shear strength parameters of the Masa-do were obtained. 


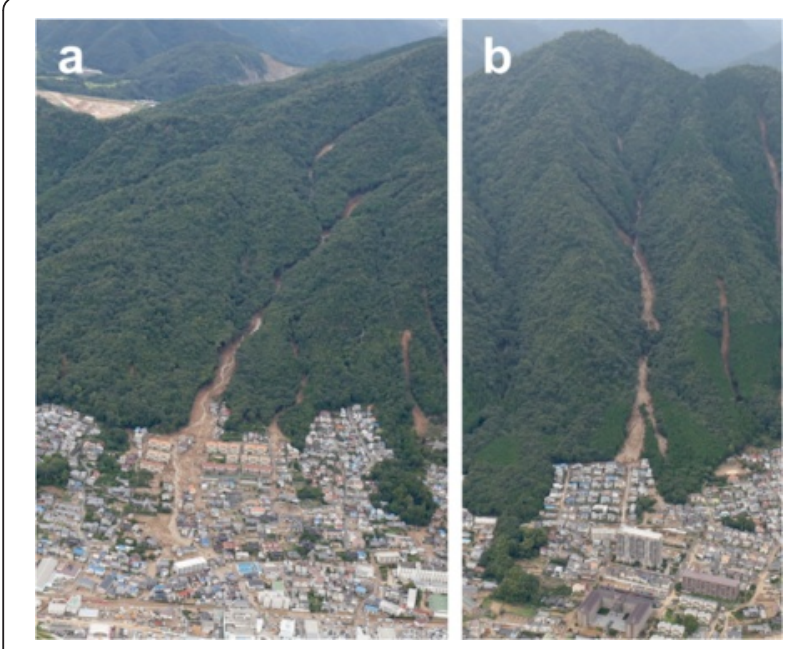

Fig. 6 Photographs of the Midori-ga-oka debris flow (a) and Abu-no-sato debris flow (b) taken on 20 August 2014 (courtesy of Geospatial Information Authority of Japan)

\section{Pore-water pressure controlled triaxial test}

With sample No. 3-DIS, the pore-water pressure controlled triaxial test was performed to simulate the initiation mechanism of shallow sliding at the source area. The slope angle of the source area is about $35^{\circ}$, and the average thickness of the initial sliding mass is about $1 \mathrm{~m}$. The potential sliding surface is located in the granitic soil above the bedrock surface.

The pore-water pressure controlled test was conducted following the procedure below.

1) Set the specimen and make it fully saturated.

2) Apply $\sigma_{1}$ and $\sigma_{3}$ as the initial axial stress and confining stress. Through this step, the initial stress condition of the slope before rainfall (without any pore-water pressure inside the slope) is simulated.

3) Apply pore-water pressure to the specimen through a pore-water pressure controller at the rate of 0.1 $\mathrm{kPa} /$ minute until specimen failure. Through this step, the situation of pore-water pressure accumulation on the potential sliding surface is simulated, and the failure process can be observed.

In this test, the slope angle was assumed to be $35^{\circ}$, and soil thickness to be one meter.

\section{Results and discussions}

Field investigation and cross section measurement of the two gullies

Based on the field investigation, the geological conditions were found to be different in the source areas of the two debris flows. The source area of the debris flow in Midori-ga-oka is composed of coarse granite, with intrusive fine granite. In the coarse granite, sheeting joints and micro-sheeting joints are well developed. The average thickness of the granitic soil is about $1 \mathrm{~m}$. In the main channel of the debris flow, all of the granitic soil was removed, and only the gully bed consisting of fresh granite was left. The situation along the gully will be introduced in details later. For the debris flow in Abu-nosato, the source area is located in hornfels. In this gully source area (where the debris flow originated), the weathered soil layer is thin, with an average thickness of $0.7 \mathrm{~m}$. The bedrock in the channel is stiff hornfels.

Figure 7 shows photographs taken along the gully of the Midori-ga-oka debris flow, from the source area to the bottom. Figure 8 shows the muddy trace of the debris flow on buildings in one of the prefectural housing areas. In the source area, two shallow slides occurred in the granitic soil. In Fig. 7a, the left-hand shallow slide (source area) has, in the upper part, a slope angle of $37.7^{\circ}$, a width of $7.9 \mathrm{~m}$ and a horizontal distance of $7.4 \mathrm{~m}$, and, in the lower part, a slope angle of $33.9^{\circ}$, similar width, and a horizontal distance of $64.5 \mathrm{~m}$. The righthand shallow slide has, in the upper part, a slope angle of $37.4^{\circ}$, width of $14.4 \mathrm{~m}$, and horizontal distance of $19 \mathrm{~m}$, and, in the lower part, a slope angle of $32.4^{\circ}$, a similar width and horizontal distance of $47.0 \mathrm{~m}$. In the travel path of the debris flow, the gully is V-shaped (Fig. 7b) in the upper part near the source area, and becomes a U-shape in the middle and lower part (Fig. 7c, e, f). There are almost no deposits in the flow channel (Fig. 7c, f). All of the debris coming from the weathered granite has been transported out of the terminal area of the debris flow channel (Fig. 7g), and deposited on the slope where a residential area is located (Fig. 7h). Fortyone lives were lost in this area, including those living in the prefectural housing and private houses. Among them, Midori-ga-oka prefectural housing that consisted of 21 three-floor reinforced concrete residential buildings, were directly hit by the debris flow (Fig. 8). It was found that in the middle and lower part of the gully, the sheeting joints were well developed (Fig. 7d). This caused the weathered granite above the major sheeting joint to easily erode away, and the volume of the debris flow became larger and the debris flow increased in magnitude and kinetic energy as it flowed down the steep gully. The material in the debris flow deposits is rich in fine soil particles, being granitic soil, or Masa-do. The fine soil particles may decrease the permeability of the debris flow, and cause greater mobility, in turn contributing to the longer travel distance and greater lateral spread. To confirm this inference, soil samples were taken from the deposition area and the grain size distribution was analyzed in the laboratory.

Figure 9 illustrates the longitudinal profile as well as the cross-sectional profiles at all measurement locations (see Fig. 5) in the gully of the Midori-ga-oka debris flow. 

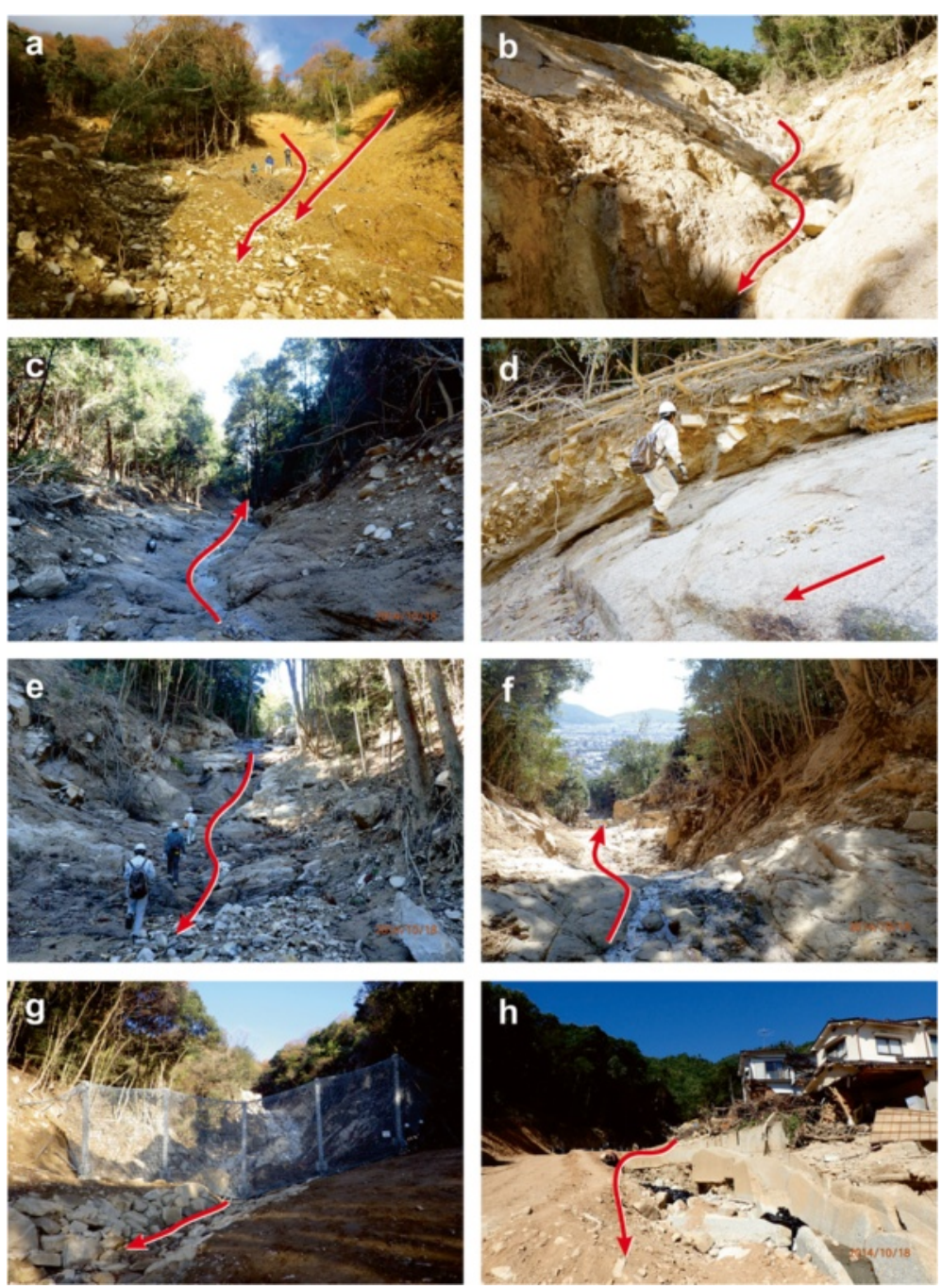

Fig. 7 Photographs showing the gully of the Midori-ga-oka debris flow. Arrows point in the downstream direction. a three branches in the source area (at cross section S-0 in Fig. 5); (b) strongly weathered granite bedrock exposed by the erosion of debris flow (S-1); (c) shallow bedrock gully after erosion by the debris flow (S-2); (d) erosion along the sheeting joints in granite (C-4); (e) bedrock gully with few debris flow deposits (C-6); (f) granite bedrock gully after extreme erosion, near the bottom of the gully (S-19); (g) the bottom of the debris flow gully, where deposits of different grain size appeared and a temporary ring net countermeasure (at S-23) was finished in December 2014; (h) severely damaged residences beside the pathway of the debris flow, these houses were built on previous debris flow deposits

From these measurements, the following aspects were evident:

1) The longitudinal profile consisted of gentle slopes (slope angle $<30^{\circ}$, indicated as S) and steep cliffs (slope angle $>40^{\circ}$, indicated as C).

2) Most of the cliffs were located at the middle and lower part of the gully.

3) The cross sections were in a V-shape from S-1 to S3 , and became U-shaped from S-5 to the end (S-21). The section became narrow in the area between $\mathrm{S}-3$ and S-17. Notably, the width change from S-15 to S-17 is very sudden. This could have caused a debris dam between S-15 and S-17, and a later collapse of the dam may have caused a debris flow of greater magnitude. This sudden narrowing in the cross section may had a significant effect on the motion of the debris flow as it flowed to the residential area, because of the constricted flow channel.

4) Nearly all of the debris deposited on the riverbed of the gentle slope in the gully (below S-23 in Fig. 5).

Figure 10 shows the Abu-no-sato debris flow gully from the source area to the deposition area. The source area is located in hard hornfels rock (Fig. 10a). The sliding direction is $\mathrm{S} 20^{\circ} \mathrm{E}$. The slope angle is $40^{\circ}$. The width is about $5 \mathrm{~m}$, the length about $30 \mathrm{~m}$, and the depth to the sliding surface, which is the outcropped bedrock, is 


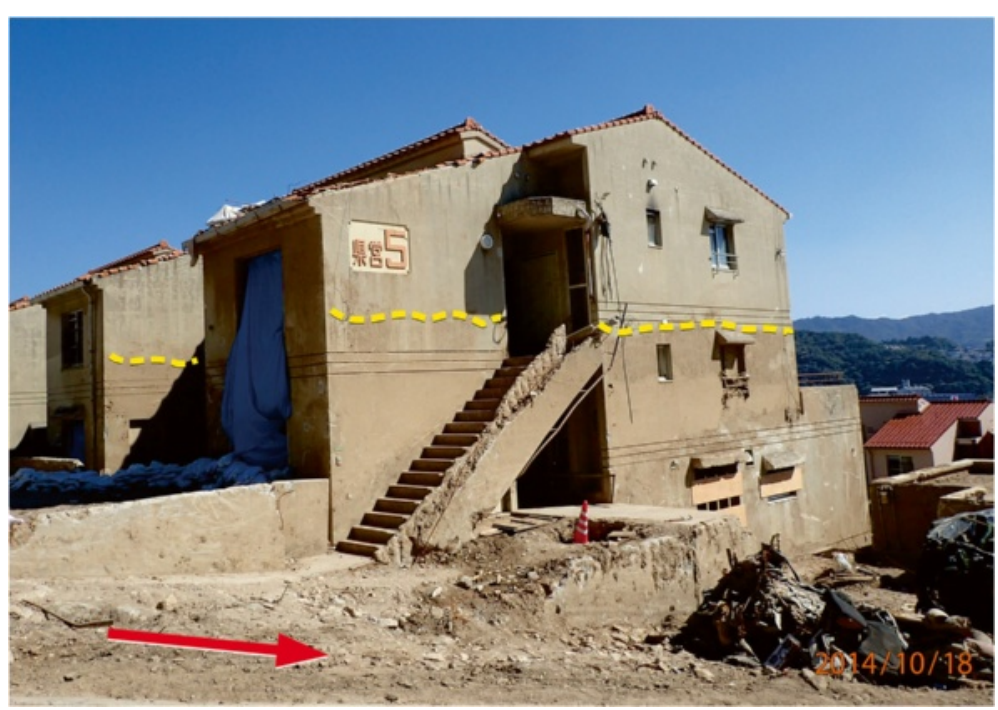

Fig. 8 The damaged prefectural housing at the pathway of the Midori-ga-oka debris flow. From the muddy trace on the wall, the flow depth of debris flow was about two-floors high

about $0.7 \mathrm{~m}$. The bedrock is fractured with joints, and two nearly vertical faults with a width of $0.15 \mathrm{~m}$ passed through the source area. After a short flow in a wide gully slope, the debris flow was limited to a narrow gully at a cliff C-3 (Fig. 10b), and dropped down, nearly vertically for about $5 \mathrm{~m}$. Lower down, it passed several slopes and cliffs, and left the hornfels area. The gully in that upper part was V-shaped, and the gully bed consisted of fractured hornfels (Fig. 10c). In some part, colluvium deposits existed in the gully (Fig. 10d). Because of the large boulder size, compared with the smaller grain size debris flow material, these would be a higher permeability, thus transportation would be less likely in this area. After flowing out of the hornfels bedrock area, and into the

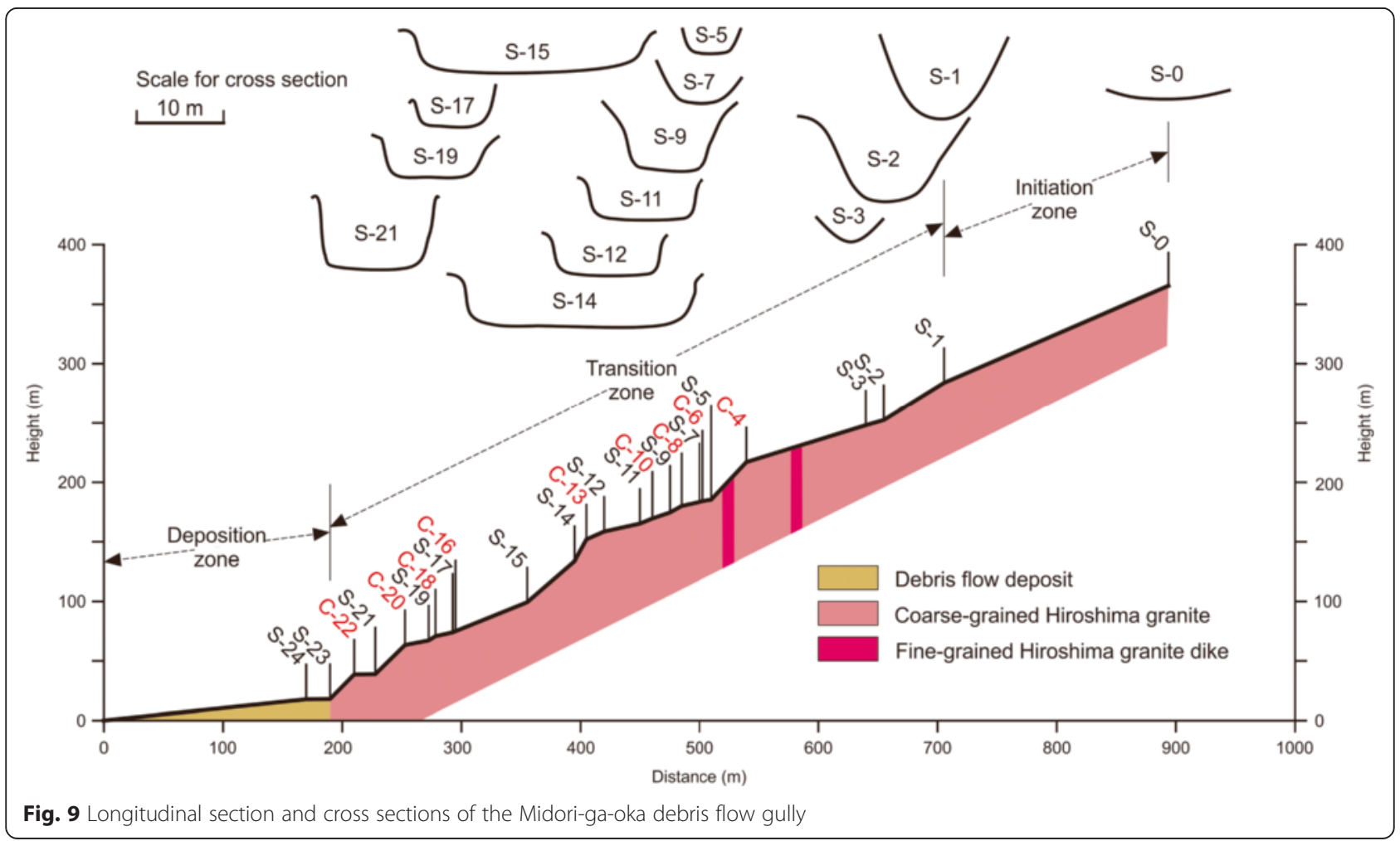



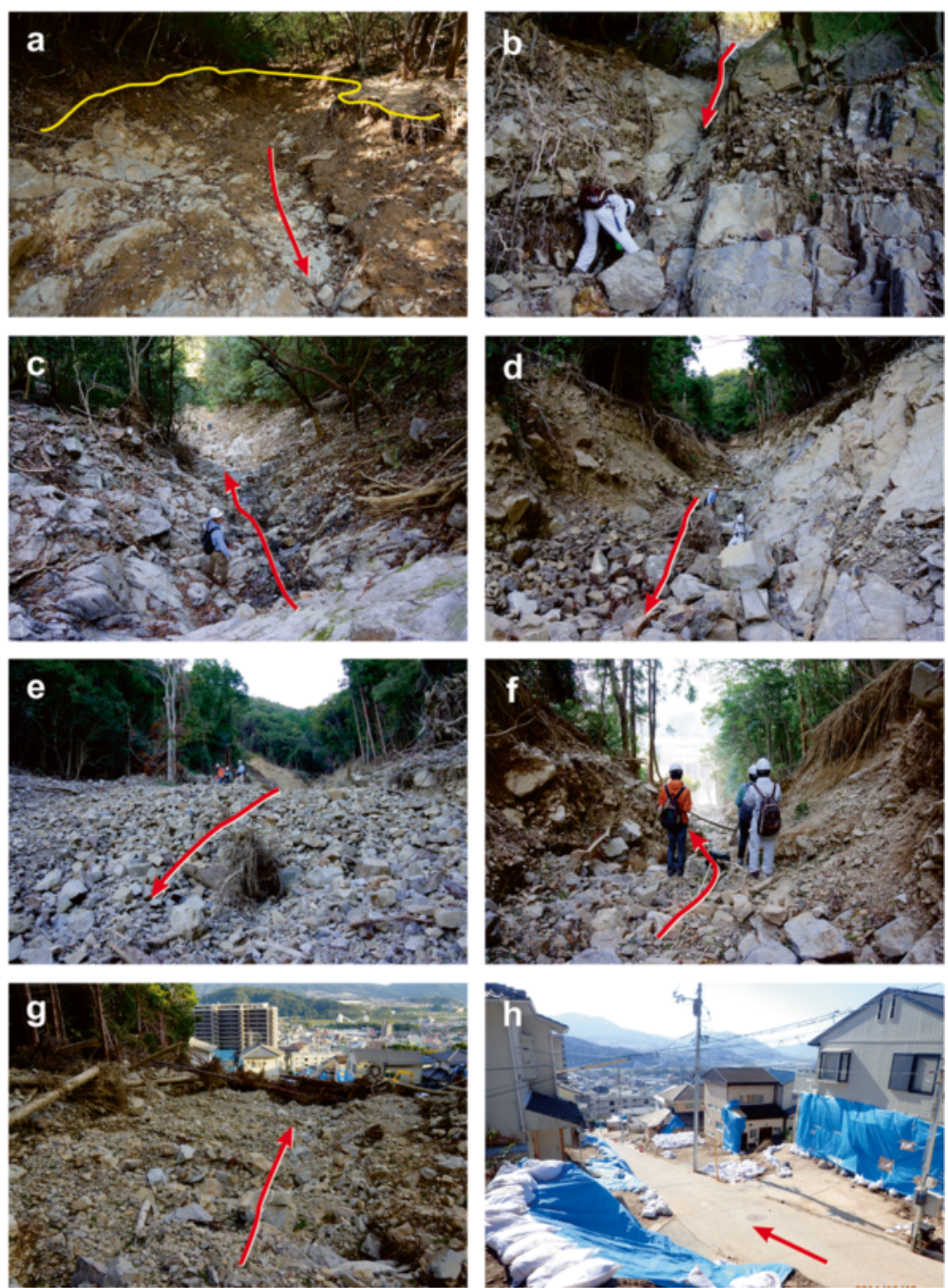

Fig. 10 Photographs in the gully of Abu-no-sato. Arrows point in the downstream direction. a source area, the scarp is marked by a yellow line (at cross section S-0); (b) cliff with a joint (C-3); (c) gully-bed with fractured rock, no deposits (S-4); (d) V-shaped gully, with colluvium from one side (S-7); (e) bottom of the gully, coarse-grained deposits of $30 \mathrm{~cm}$ average diameter was widely distributed (S-14); (f) narrow neck of the gully (S-16); (g) downstream deposit area with shallow coarse-grained layer (S-19); (h) the houses along a road damaged by the debris flow in the Abu-no-sato community

coarse granite bedrock area, the slope angle became gentle $\left(17.7^{\circ}\right)$, and most of the boulders deposited at the bottom of the gully (Fig. 10e). Because the content of the debris flow is composed of boulders, most of the boulders were deposited in the gentle and wide slope before they reached the residential area as pore water pressure reduced rapidly. However, an old debris flow deposit terrace caused a dam of the debris flow. Collapse occurred at both sides of the terrace, and deep erosion developed (Fig. 10f shows the right side narrow channel). Through the narrow channels, part of the debris flow including boulders and fallen trees were deposited on a wide gentle slope (Fig. 10g). A small amount of debrisflow material flowed beyond the boundary between the natural slope and the residential area (a local road), destroyed two houses and caused 4 deaths. Some houses along the slope road (see Fig. 6b) were damaged to different extents, mainly by rolling boulders and rapid water flow.

Figure 11 illustrates the longitudinal section and cross sections at all measurement locations (see Fig. 5) in the gully of Abu-no-sato debris flow. From the information in the figure, the following effects can be observed.

1) The slope was steep in the hornfels area, and became gentle in the coarse-grained granite area.

2) Most of the cliffs were distributed in the middle and upper parts of the gully.

3) The gully was V-shaped in most of the hornfels area, and gradually became wider. 


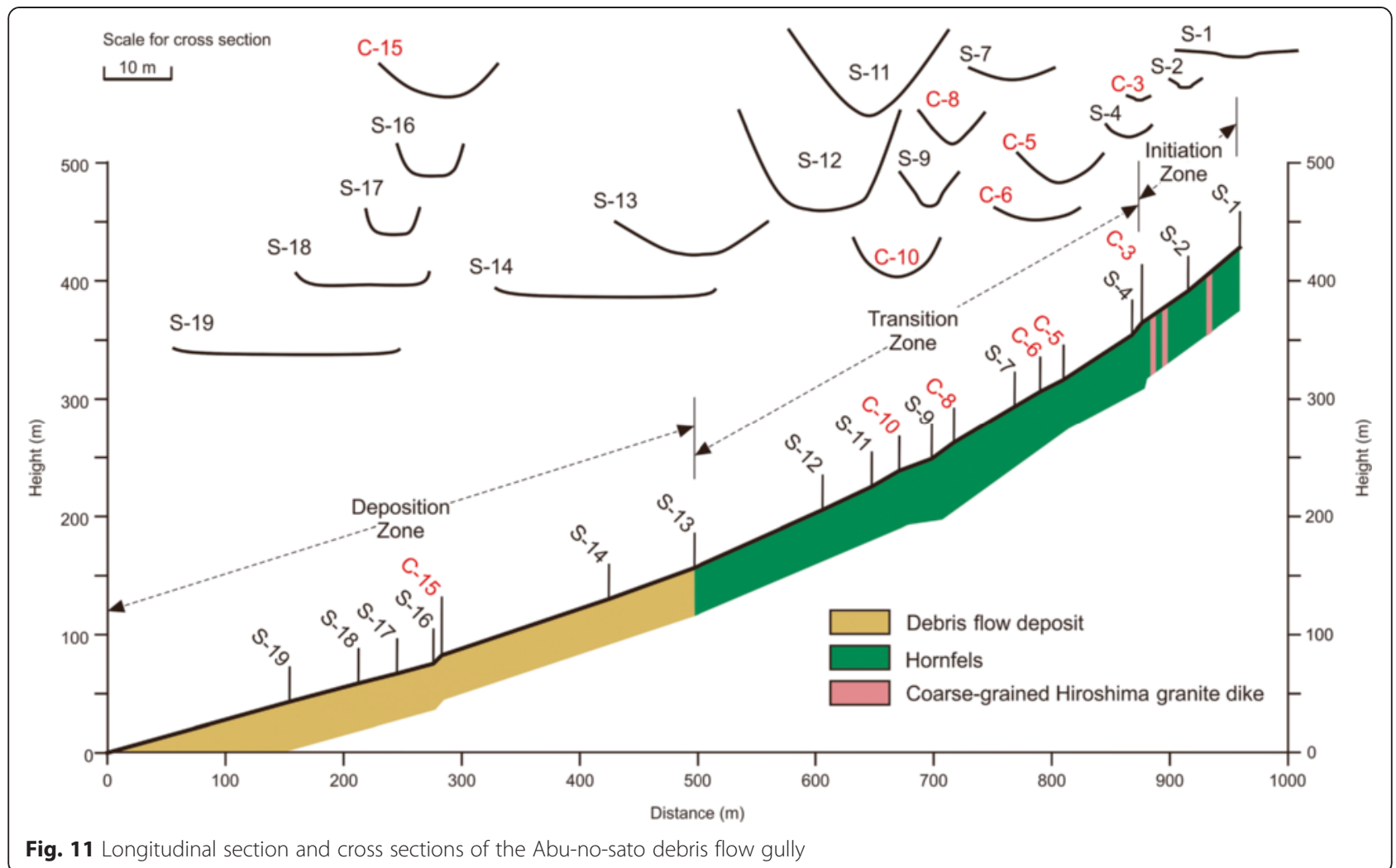

4) From $\mathrm{C}-15$ to $\mathrm{S}-17$, the cross sections narrowed rapidly. This change may have caused a dam in the debris flow, and the later outburst may be a direct cause of the disaster.

Compared with the Midori-ga-oka debris flow, the distance between the residential area and the starting point of the deposition area is much larger in Abu-no-sato debris flow. It may mean that keeping enough space between the deposition start point and the residential area is very important for disaster reduction.

\section{Soil properties: in-situ density and grain size distribution}

The locations of sample Nos. 1-6 are illustrated in Fig. 5. Table 1 shows the physical parameters of undisturbed sample Nos. 1, 2 and 3. The value of specific gravity for

Table 1 Parameters of soil samples in the source area of the Midori-ga-oka gully

\begin{tabular}{llll}
\hline Sample No. & 1 & 2 & 3 \\
\hline Specific gravity, $G_{S}$ & 2.640 & 2.643 & 2.638 \\
Dry density, $\rho_{\mathrm{d}}\left(\mathrm{kg} / \mathrm{m}^{3}\right)$ & 1,370 & 1,390 & 1,189 \\
Water content, $w(\%)$ & 15.2 & 19.5 & 31.5 \\
Liquid limit, $L L(\%)$ & - & - & 32.1 \\
Plastic limit, $P L(\%)$ & - & - & 23.4 \\
Plasticity Index, $P$ (\%) & - & - & 8.7 \\
\hline
\end{tabular}

all samples is around 2.64. Samples Nos. 1 and 2 are from the same landslide, and have similar properties. The dry densities of sample Nos. 1 and 2 are higher than that of sample No. 3.

Figure 12 illustrates the grain size distribution of all samples (Nos. 1-6). Sample Nos. 1 to No. 5 are from the Midori-ga-oka debris flow gully. Nos. 1, 2, and 3 are from the source area, and Nos. 4 and 5 are from the exit of the gully, the first deposit of the debris flow. Sample No. 3 comprises much finer particles than the other samples, and the mean grain size $D_{50}$ is $0.035 \mathrm{~mm}$. While the mean grain sizes of samples Nos. 1, 2, 4 and 5 are close to $1 \mathrm{~mm}$, their distributions are also similar. Comparing the sample from the deposition area with that from the source area, the grain size is not much different. The amount of fine particles is slightly less in the deposition area. This may mean that the finer particles are transported for a longer distance. Sample No. 6 is from the lower part of the deposition area of the Abuno-sato debris flow, which has the smallest grain size in the debris flow deposit. In the upstream part, the deposit generally consists of boulders with a mean size of $0.3-$ $0.5 \mathrm{~m}$, and a maximum size up to $1.5-2.0 \mathrm{~m}$. From the grain size distribution, it can be seen that the particles in the Midori-ga-oka debris and the Abu-no-sato debris flows are different in grain size and, in turn, we can infer that they have different permeability and drainage 


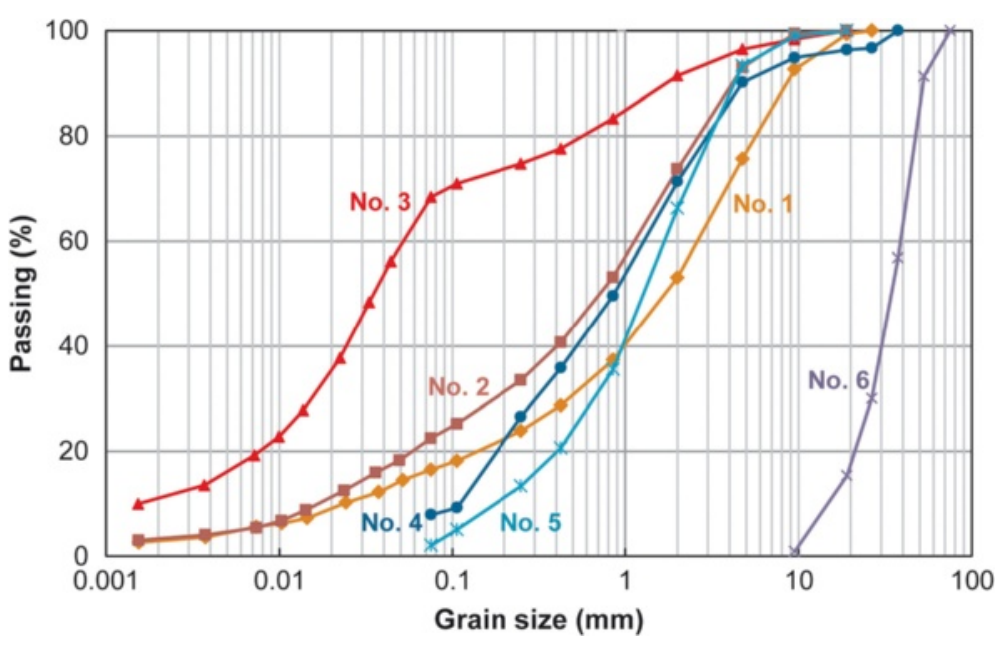

Fig. 12 Grain size distribution of samples Nos. 1-6

characteristics. At a given travel velocity, the low permeability, which is associated with a slower rate of drainage of the debris at Midori-ga-oka (mainly consisting of granitic soil), may mean that the flow has greater mobility and may travel for a longer distance because it remains in the saturated condition for longer. The boulders in the Abu-no-sato debris flow mean that deposition occurs much earlier as the debris drains rapidly and changes to the unsaturated condition. The critical velocity of a debris flow transformed from saturated to unsaturated condition will be of significance in predicting the run-out mobility of debris flow.

Composed of $70 \%$ of particles finer than $0.1 \mathrm{~mm}$, sample No. 3 was used to conduct the Atterberg limit tests. The results are shown in Table 1 . In addition, Fig. 13 shows that the soil classification of the sample No. 3 is between Silt (ML) and Low plasticity Clay (CL) with a low liquid limit (ASTM D2487-11 2011).

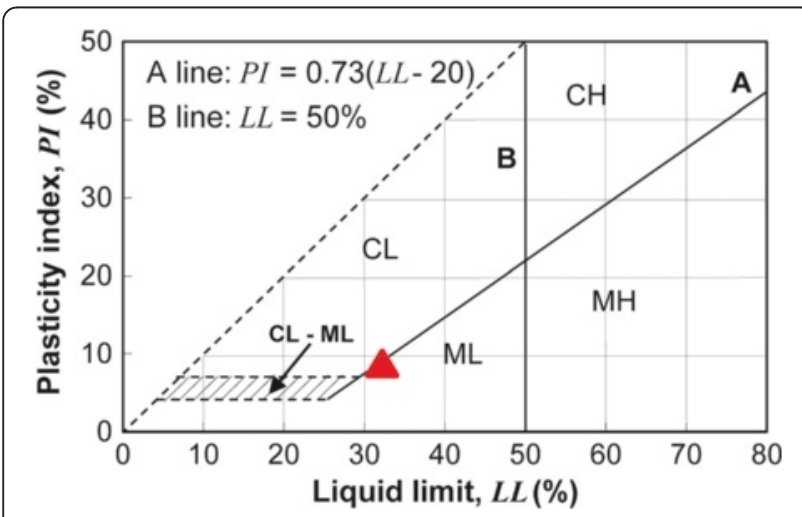

Fig. 13 Plasticity chart of sample No. 3 (red solid triangular). Modified from ASTM D2487-11 (2011). CL = Lean clay; ML = silt

\section{Geochemical analysis of the granite sample}

Major element compositions of the fresh granite, the weathered granite, and the granitic soil in the Midoriga-oka gully are listed in Table 2 . The fresh granites are hard rocks and the constituent minerals are mostly unaltered. The weathered rocks are relatively hard, but are discolored to yellowish white. Plagioclase has changed color to creamy white. Fe (iron) stains surround the biotite and other minerals. The granitic soils are mainly composed of clays, along with less than half the amount of fine altered minerals. Small quartz grains are sometimes visible.

The Chemical Index of Alteration (CIA, defined by Nesbitt and Young 1982) is employed to investigate the degree of chemical weathering of the collected samples, as it is well known as a functional tool to estimate the weathering state of granitic rocks (e.g., Fedo et al. 1995; Kamei et al. 2012). The Eq. (1) is the formula.

$$
\text { CIA }=100 \times \mathrm{Al}_{2} \mathrm{O}_{3} /\left(\mathrm{Al}_{2} \mathrm{O}_{3}+\mathrm{CaO} *+\mathrm{Na}_{2} \mathrm{O}+\mathrm{K}_{2} \mathrm{O}\right) \text { molar basis }
$$

Where $\mathrm{CaO}^{*}$ represents $\mathrm{Ca}$ in the silicate fraction only. Fresh granitic rocks generally have CIA values near 50 . $\mathrm{Al}_{2} \mathrm{O}_{3}$ is less mobile during the weathering process, whereas $\mathrm{CaO}^{*}, \mathrm{Na}_{2} \mathrm{O}$, and $\mathrm{K}_{2} \mathrm{O}$ are relatively more mobile (e.g., Nesbitt and Young 1982; Harnois 1988; Fedo et al. 1995). Consequently, CIA values gradually increase with increasing intensity of rock weathering up to a value of 100 . The CIA values of the fresh granites, the weathered granites, and the granitic soils of Midori-gaoka are 52.6-54.5, 53.1-55.5, and 56.4-69.9, respectively (Table 2). We especially focused on the lower CIA values of the granitic soils.

Nesbitt and Markovics (1997) reported the CIA values of typical clay-rich weathered granitoids (72.7-81.6) 
Table 2 Major element compositions of granite and related samples in the Midori-ga-oka gully

\begin{tabular}{lllllllllllllll}
\hline Location & $\mathrm{Type}$ & $\mathrm{SiO}_{2}$ & $\mathrm{TiO}_{2}$ & $\mathrm{Al}_{2} \mathrm{O}_{3}$ & $\mathrm{Fe}_{2} \mathrm{O}_{3}$ & $\mathrm{MnO}$ & $\mathrm{MgO}$ & $\mathrm{CaO}$ & $\mathrm{Na}_{2} \mathrm{O}$ & $\mathrm{K}_{2} \mathrm{O}$ & $\mathrm{P}_{2} \mathrm{O}_{5}$ & LOI & Total & $\mathrm{ClA}$ \\
\hline $\mathrm{G} 1$ & $\mathrm{FG}$ & 72.58 & 0.23 & 14.97 & 2.45 & 0.05 & 0.50 & 1.75 & 3.10 & 4.10 & 0.03 & 0.71 & 100.47 & 54.2 \\
$\mathrm{G} 1$ & $\mathrm{GS}$ & 71.74 & 0.31 & 14.74 & 3.24 & 0.08 & 0.62 & 1.66 & 2.79 & 3.52 & 0.01 & 1.96 & 100.66 & 56.4 \\
$\mathrm{G} 2$ & $\mathrm{FG}$ & 74.59 & 0.19 & 13.80 & 2.21 & 0.05 & 0.43 & 1.18 & 2.92 & 4.26 & 0.02 & 0.80 & 100.45 & 54.5 \\
$\mathrm{G} 2$ & $\mathrm{GS}$ & 69.46 & 0.29 & 16.43 & 2.89 & 0.16 & 0.54 & 0.67 & 1.88 & 3.71 & 0.04 & 5.20 & 101.27 & 66.6 \\
$\mathrm{G} 2$ & $\mathrm{GS}$ & 67.20 & 0.38 & 17.87 & 3.38 & 0.19 & 0.66 & 0.45 & 1.71 & 3.87 & 0.05 & 6.09 & 101.85 & 69.9 \\
$\mathrm{G} 3$ & $\mathrm{FG}$ & 73.69 & 0.25 & 13.80 & 2.87 & 0.06 & 0.57 & 1.64 & 2.91 & 3.98 & 0.04 & 0.52 & 100.33 & 53.5 \\
$\mathrm{G} 3$ & $\mathrm{GG}$ & 72.45 & 0.26 & 14.55 & 2.68 & 0.08 & 0.56 & 1.56 & 2.85 & 3.84 & 0.02 & 1.79 & 100.65 & 55.5 \\
$\mathrm{G} 3$ & $\mathrm{GS}$ & 72.78 & 0.26 & 14.56 & 2.59 & 0.13 & 0.51 & 1.01 & 2.43 & 3.80 & 0.00 & 2.75 & 100.81 & 59.4 \\
$\mathrm{G} 4$ & $\mathrm{FG}$ & 76.52 & 0.11 & 12.85 & 1.65 & 0.04 & 0.31 & 1.08 & 2.92 & 4.50 & 0.01 & 0.19 & 100.17 & 52.6 \\
$\mathrm{G} 4$ & WG & 76.39 & 0.12 & 12.87 & 1.64 & 0.04 & 0.32 & 1.04 & 2.89 & 4.37 & 0.01 & 0.44 & 100.14 & 53.1 \\
$\mathrm{G} 4$ & $\mathrm{GS}$ & 72.72 & 0.23 & 14.55 & 2.38 & 0.08 & 0.45 & 0.79 & 2.25 & 3.86 & 0.02 & 3.44 & 100.78 & 61.1 \\
\hline
\end{tabular}

G1 to G4: sample locations, showing in Fig. 5. FG Fresh granite, WG Weathered granite, GS Granitic soil, LOI loss on ignition, CIA Chemical Index of Alteration (Nesbitt and Young, 1982)

from the outer layer of the spheroidal weatheringboulder in Toorongo granodiorite, Australia. The weathering conditions of the sample location are similar to those of Hiroshima Prefecture. Summers of both regions are warm, averaging $25-30{ }^{\circ} \mathrm{C}$, and winters are cold with temperatures of -5 to $10{ }^{\circ} \mathrm{C}$. Summer precipitation is 200-300 $\mathrm{mm}$ with annual precipitation approximately $1,500 \mathrm{~mm}$ for both. As a result of the similarities, the CIA values of Toorongo granodiorite would be a good comparison with our samples. However, the granitic soils of Midori-ga-oka have significantly lower CIA values (56.4-69.9) compared with those of the weathered granitoids in Toorongo granodiorite (72.7-81.6). This suggests that the degree of chemical weathering of the granitic soils in the Midori-ga-oka gully is less than that of normally weathered granitic materials. This provides the evidence that the weathered materials in the shallow slide area were in a removal cycle from the steep slope, due to repeated debris flows. Therefore, the lower CIA values of soil materials in debris flows may be a good indicator in order to detect the active area of debris flows in a granitic region.

\section{Consolidated-undrained triaxial compression tests}

The stress-strain relation of the consolidated-undrained tests on the saturated specimen (Fig. 14a) shows that the deviatoric stress increases in the beginning. When the axial strain is about $2 \%$, the deviatoric stress reaches the peak value. After that, the deviatoric stress turns to decrease with the axial strain. Bulging failure was observed for all specimens at the end of the tests. The stressstrain curves indicate that the critical state of the soil will be reached at low strains value.

The relation between excess pore-water pressure and the axial strain in the consolidated-undrained tests on saturated specimens is shown in Fig. 14b. Positive excess pore-water pressure was generated in all three undrained tests. In all soil specimens, the positive excess porewater pressure increases to a high value with minor strain, and increases slowly as the strain increases
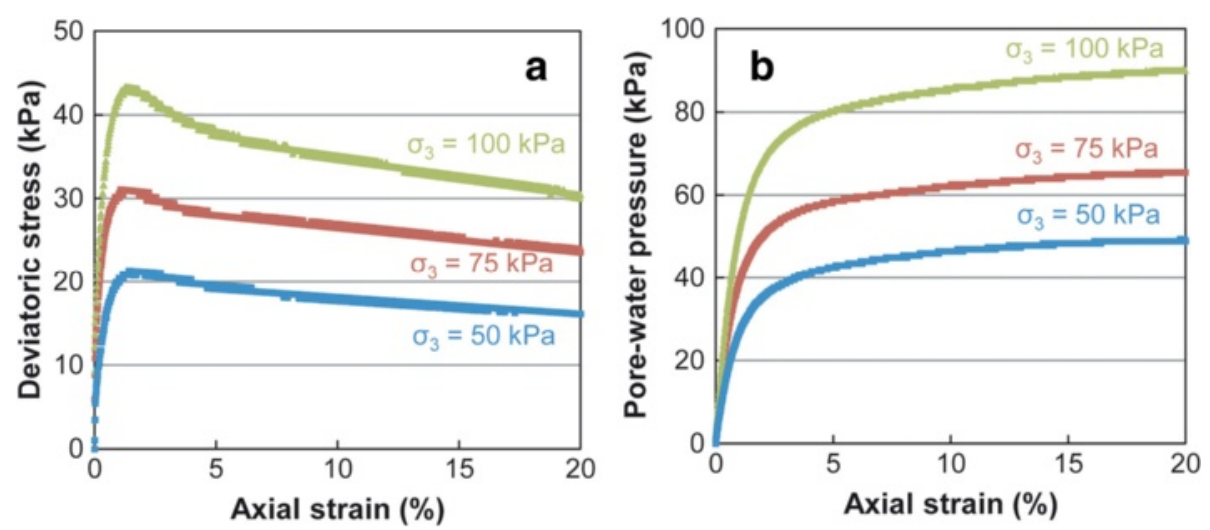

Fig. 14 Results of the consolidated undrained test: (a) stress-strain relation; (b) relation between pore-water pressure and axial strain 
continuously. Finally, the value of pore-water pressure is close to the confining pressure, indicating that the soil would liquefy if the strain continued to increase.

All of the effective stress paths show a similar trend. Each path moves to the right initially (increasing $\left(\sigma_{1}^{\prime}+\sigma_{3}^{\prime}\right) / 2$ ), and then moves toward the left (decreasing $\left(\sigma_{1}^{\prime}+\sigma_{3}^{\prime}\right) / 2$ ) until reaching the critical state line (CSL) at the end of the test. The critical states of the saturated specimens can be represented by the CSL in the stress plane, as shown in Fig. 15. The gradient of the critical state line is 0.404 . This corresponds to an internal effective friction angle of $23.8^{\circ}$ and cohesion of 5.5 $\mathrm{kPa}$ of the granitic soil.

\section{Pore-water pressure controlled triaxial test}

To determine the initial stress condition of soil sample No. 3-DIS, the thickness $(H)$ of the soil layer and slope angle $(\alpha)$ are assumed as $1 \mathrm{~m}$ and $35^{\circ}$, respectively, based on the field measurement results in the source area of the debris flow. As shown in Table 1, the unit weight $(\gamma)$ of the natural soil is $15.6 \mathrm{kN} / \mathrm{m}^{3}$. From consolidated undrained triaxial tests, the internal effective friction angle $\left(\phi^{\prime}\right)$ of the soil is $23.8^{\circ}$. The initial maximum principal stress $\left(\sigma_{1}\right)$ and minimum principal stress $\left(\sigma_{3}\right)$ are 21.7 and $5.7 \mathrm{kPa}$, respectively. Through the pore-water pressure controlled triaxial test, the relations between deviatoric stress, axial strain and pore-water pressure were obtained (Fig. 16).

Figure 16 shows that, when the pore-water pressure increased to about $4.0 \mathrm{kPa}$, the deviatoric stress started to decrease, while the axial strain increased. The same soil behavior also can be found in Fig. 17. The effective stress path begins to go down when pore-water pressure increases to about $4.0 \mathrm{kPa}$ (point B). After this point, yielding occurs, and the effective stress path moves downward and to the left, then reaches the critical state line (point $C$, where pore-water pressure is $6.5 \mathrm{kPa}$ ). This shows the major failure of the soil. With the continuous supply of pore-water pressure, the stress path moves down and left

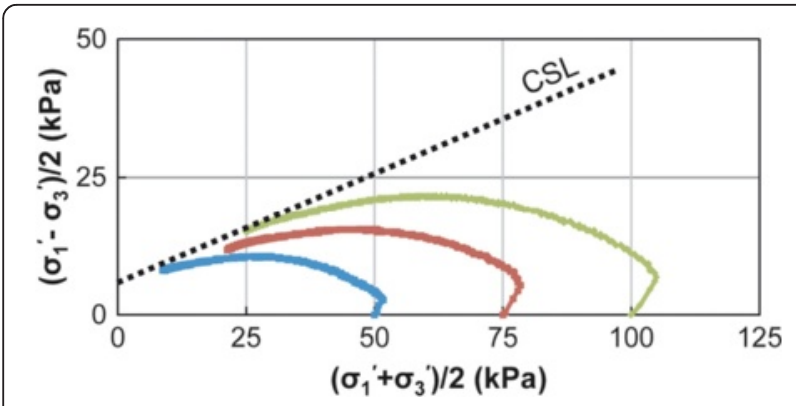

Fig. 15 Effective stress paths under different confining pressures (50, 75 and $100 \mathrm{kPa}$ ), the dotted line indicated the critical state line (CSL)

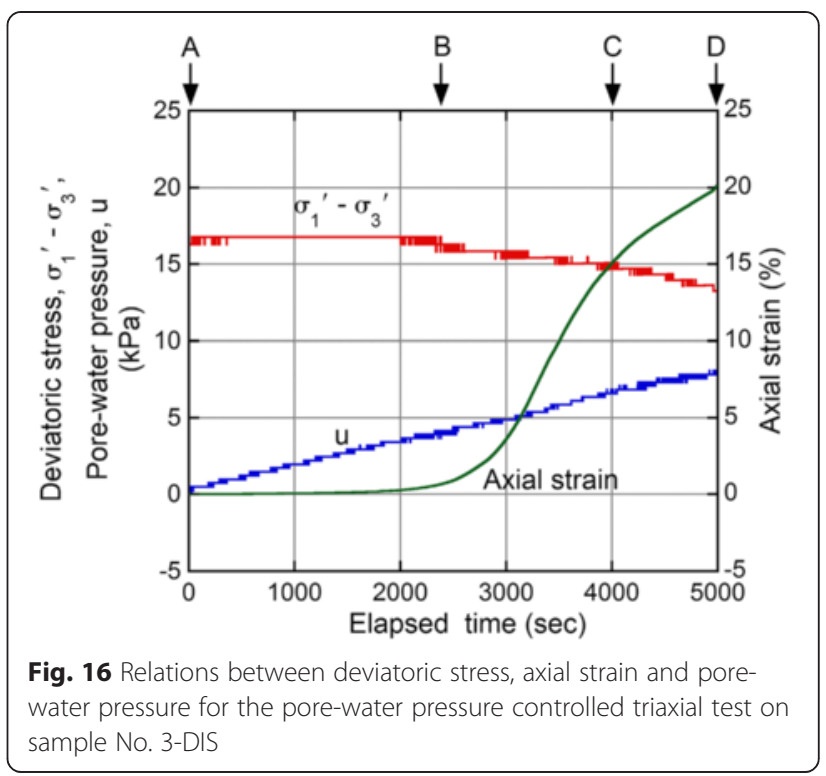

along the critical state line, and ends at point $\mathrm{D}$, where the pore-water pressure is $8.3 \mathrm{kPa}$. This simulation test can explain the initiation mechanism of the shallow landslide that occurred on a steep slope. During heavy rainfall, continuous rainfall infiltration can generate a wet front in the soil slope and in turn form a saturated zone above the potential sliding surface. Gradually, the saturated zone will move upwards in relation to the slope surface, and the pore-water pressure acting on the potential sliding surface will increase. Finally, it will cause shallow landslide. Because this phenomenon occurs in steep slopes, it will create a debris flow moving downward for a long distance. From the test, we can see that, with low pore-water

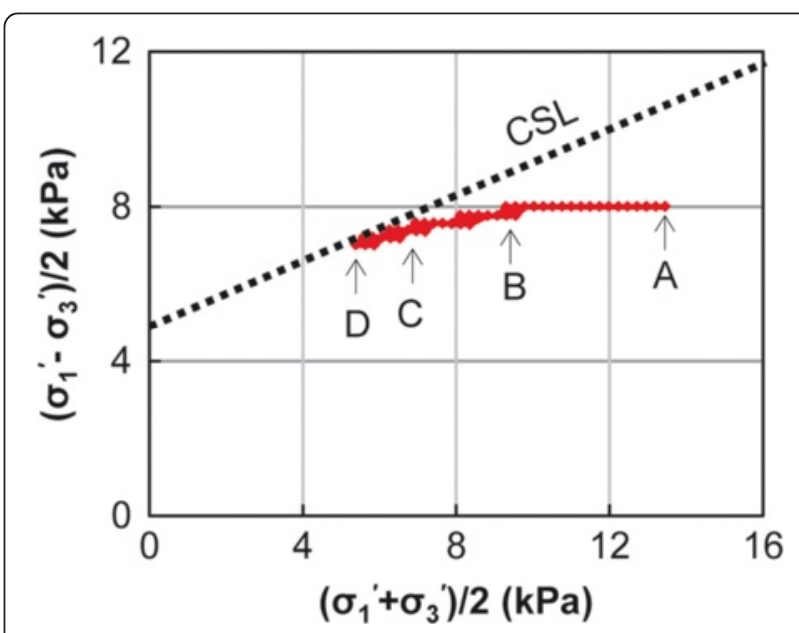

Fig. 17 Effective stress paths of pore-water pressure controlled triaxial test, the dotted line indicates the critical state line (CSL) obtained in undrained tests 
pressures (i.e., when the rainfall is not so heavy), the slope can maintain stability. However, if the pore-water pressure exceeds the critical value, as a result of heavy rainfall, for example, shallow landslide will be triggered. In this simulation test, the critical value of the pore-water pressure is about $4.0 \mathrm{kPa}$. Considering the slope angle of the source area is $35^{\circ}$, and the thickness of the initial sliding mass is $1 \mathrm{~m}$, the pore-water pressure of $4.0 \mathrm{kPa}$ and $6.5 \mathrm{kPa}$ mean that the groundwater levels are about $0.60 \mathrm{~m}$ and $0.97 \mathrm{~m}$ high, respectively, above the sliding surface. So when the groundwater level rises to $0.6 \mathrm{~m}$ above the potential sliding surface, instability may occur in the slope, and deformation may develop. When the groundwater level rises to $0.97 \mathrm{~m}$, the slope will completely fail. For a slope with depth of $1 \mathrm{~m}$, the groundwater level of $0.97 \mathrm{~m}$ almost means the existence of surface flow along the slope. These two values of the groundwater level may be used as a reference for the prediction of shallow landslide initiation under similar condition. Since the soil sample used for triaxial tests is disturbed soil, the in-situ critical value of the pore-water pressure may be slightly higher than experimental value. However, using a smaller value is conservative, erring on the side of community safety.

\section{Conclusions}

Based on field investigations and laboratory tests, the following conclusions are reached.

1) Under extreme high intensity and short duration rainstorm, debris flows occurred on very steep slopes with a thin initiating sliding mass in weathered coarse-grained granite and hornfels.

2) Cross sectional properties of the debris flow gully, especially gully shape and changes in width, have important implications for debris flow damming, travel distance, and deposition.

3) During travel, the debris flow may erode the valley and carry the colluvium and valley deposits downslope. Shallow slides in high mountains can cause large-scale debris flow.

4) Debris flows that are rich in fine particles like granitic soil, tend to travel long distances until they flow onto very gentle slopes, while those with boulders as components started to deposit as soon as the valley became wide and gently-sloped. The permeability and drainage characteristics of the debris flow controlled the travel distance of the debris flow.

5) The degree of chemical weathering of the granitic soils in the Midori-ga-oka gully is less than that of normally weathered granitic materials. This provides the evidence that the weathered materials in the shallow slide area were in a removal cycle from the steep slope, due to repeated debris flows.
6) Simulation test with pore-water pressure controlled triaxial test shows reasonable response of soil behavior under different water pressure conditions, which corresponds to groundwater level in a real slope. It is hoped that the groundwater level in a real slope can be used for failure prediction.

\section{Competing interests}

The authors declare that they have no competing interests.

\section{Authors' contributions}

All authors participated the field investigation; FW prepared the first draft of the paper; HY conducted the soil tests in laboratory; YHW and ST prepared the sections and profiles; AK made the geochemical analysis on the granite sample. All authors read and approved the final manuscript.

\section{Acknowledgements}

Based on the field investigation experiences, we like to make some suggestions for countermeasure works to prevent debris flow disasters: (a) Keeping enough distance between the residential area and the deposition area of the debris flow is essential; (b) For the hornfels area, a ring-net will be effective to stop the travel of boulders; (c) For weathered granite area, the use of a ring-net to stop large boulders and, in addition, building a large catch pit with a check dam will be effective; (d) Because debris flows always move rapidly, early warning should be sufficiently timely, such people have time to take action. Otherwise, delayed warnings are useless when considering the weather condition that can cause debris flows.

This investigation was financially supported by a fund for exploratory research from Shimane University, JSPS KAKENHI Grant Number A-2424106 for landslide dam failure prediction. The students from Department of Geoscience, Shimane University, Ryoichi Tsukamoto, Tomohiro Oda, Norisato Oishi, Naho Yamamoto, Masafumi Yokoyama joined the field investigation and assisted the topographic survey and soil/rock sampling. Lynn Highland of U.S. Geological Survey made constructive comments of the draft. Valuable and constructive comments from anonymous reviewers are deeply appreciated.

Received: 13 February 2015 Accepted: 30 June 2015

Published online: 24 July 2015

\section{References}

ASTM D2487-11 (2011) Standard Practice for Classification of Soils for Engineering Purposes (Unified Soil Classification System). ASTM International, West Conshohocken, PA. doi:10.1520/D2487-11

Casagli N, Dapporto S, Ibsen ML, Tofani V, Vannocci P (2006) Analysis of the landslide triggering mechanism during the storm of 20th-21st November 2000, in Northern Tuscany. Landslides 3(1):13-21

Cevaso A, Pepe G, Brandolini P (2014) The influence of geological and land use settings on shallow landslides triggered by an intense rainfall event in a coastal terraced environment. Bull Eng Geol Environ 73:859-875

Chen SC, Chou HT, Chen SC, Wu CH, Lin BS (2014) Characteristics of rainfallinduced landslides in Miocene formations: a case study of the Shenmu watershed, Central Taiwan. Eng Geol 169:133-146

Dijkstra TA, Wasowski J, Winter MG, Meng XM (2014) Introduction to geohazards of Central China. Q J Eng Geol Hydrogeol 47(3):195-199

Duan W, He B, Takara K, Luo P, Nover D, Yamashiki Y, Huang W (2014) Anomalous atmospheric events leading to Kyushu's flash floods, July 11-14, 2012. Nat Hazards 73:1255-1267

Fedo CM, Nesbitt HW, Young GM (1995) Unraveling the effects of potassium metasomatism in sedimentary rocks and paleosols, with implications for paleoweathering conditions and provenance. Geology 23:921-924

García-Martínez R, López JL (2005) Debris flows of December 1999 in Venezuela. In: Jakob M, Hungr O (eds) Debris-flow Hazards and Related Phenomena, 519-538, Springer

Harnois L (1988) The CIW index: a new chemical index of weathering. Sediment Geol 55:319-322

Hiroshima Prefecture (2014) Monitoring information in Hiroshima Prefecture., http://www.bousai.pref.hiroshima.jp/info/disp?disp=R60100\&fmode= 1\&year=2014\&month=8, Accessed 20 Dec 2014 (In Japanese) 
Japan Meteorological Agency (2015) The Query of Past Meteorological Data., http://www.data.jma.go.jp/obd/stats/etrn/index.php. Accessed 5 Jan 2015 (In Japanese)

Kamei A, Fukushi K, Takagi T, Tsukamoto H (2012) Chemical overprinting of magmatism by weathering: a practical method for evaluating the degree of chemical weathering of granitoids. Appl Geochem 27:796-805

Kimura J-I, Yamada Y (1996) Evaluation of major and trace element analyses using a flux to sample ratio of two to one glass beads. J Min Petrol Econ Geol 91:62-72

Lepore C, Kamal SA, Shanahan P, Bras RL (2012) Rainfall-induced landslide susceptibility zonation of Puerto Rico. Environ Earth Sci 66:1667-1681

Ministry of Land, Infrastructure, Transport and Tourism (2014) Report of countermeasure of slopeland disasters in Hiroshima triggered by heavy rainfall in August, 2014., http://www.mlit.go.jp/river/sabo/H26_hiroshima/ 141031_hiroshimadosekiryu.pdf. Accessed 5 Jan 2015 (in Japanese)

Montgomery DR, Schmidt KM, Dietrich WE, McKean J (2009) Instrumental record of debris flow initiation during natural rainfall: implications for modeling slope stability. J Geophysics Res-Earth 114:F01031

Nesbitt HW, Markovics G (1997) Weathering of granodioritic crust, long-term storage of elements in weathering profiles, and petrogenesis of siliciclastic sediments. Geochim Cosmochim Acta 61:1653-1670

Nesbitt HW, Young GM (1982) Early Proterozoic climates and plate motions inferred from major element chemistry of lutites. Nature 199:715-717

$\mathrm{Ni} \mathrm{H}$, Zheng W, Song Z, Xu W (2014) Catastrophic debris flows triggered by a 4 July 2013 rainfall in Shimian, SW China: formation mechanism, disaster characteristics and the lessons learned. Landslides 11(5):909-921

Okada Y, Kurokawa U (2015) Examining effects of tree roots on shearing resistance in shallow landslides triggered by heavy rainfall in Shobara in 2010. J For Res 20:230-235

Saito H, Matsuyama H (2012) Catastrophic landslide disasters triggered by recordbreaking rainfall in Japan: their accurate detection with normalized soil water index in the Kii peninsula for the year 2011. SOLA 8:81-84

Takahashi Y (2014) The 2014.8.20 sediment disasters in Hiroshima, especially on the geological factors., http://www.geosociety.jp/hazard/content0082.html, Accessed 3 Nov 2014 (In Japanese)

Tang C, van Asch TWJ, Chang M, Chen GQ, Zhao XH, Huang XC (2012) Catastrophic debris flows on 13 August 2010 in the Qingping area, southwestern China: the combined effects of a strong earthquake and subsequent rainstorms. Geomorphology 139-140:559-576

The Chugoku Shimbun Online (1999) Hazardous area expands while 26 people dead and 9 missing., http://web.archive.org/web/20080316224507/http:// www.chugoku-np.co.jp/News/990629_gouu/Tn99070101.html. Accessed 17 Jan 2015 (in Japanese)

The Japan Times (2014) Mudslides kill 36 in Hiroshima., http:// www.japantimes.co.jp/news/2014/08/20/national/least-eight-dead-hiroshimalandslides-floods/\#.VKpOensXd0Z. Accessed 5 Dec 2014

Tsuchida T, Kano S, Nakagawa S, Kaibori M, Nakai S, Kitayama N (2014) Landslide and mudflow disaster in disposal site of surplus soil at Higashi-Hiroshima due to heavy rainfall in 2009. Soils Found 54(4):621-638

Wang G, Sassa K, Fukuoka H (2003) Downslope volume enlargement of a debris slide-debris flow in the 1999 Hiroshima, Japan, rainstorm. Eng Geol 69:309-330

Winter MG, Harrison M, Macgregor, Shackman L (2013) Landslide hazard assessment and ranking on the Scottish road network. Proceedings, Institution of Civil Engineers (Geotechnical Engineering), 166(GE6), 522-539.. doi:10.1680/geng.12.00063

Yamamoto H, Kobayashi $\mathrm{H}$ (2014) Characteristics of heavy rainfall and debris flow disaster in Hiroshima City by Akisame-front, 20 August 2014. J Jpn Soc Nat Disaster Sci 33(3):293-312 (in Japanese with English Abstract)

Yang H, Wang F, Miyajima M (2015) Investigation of shallow landslides triggered by heavy rainfall during typhoon Wipha (2013), Izu Oshima Island, Japan. Geoenvironmental Disasters 2:15. doi:10.1186/s40677-015-0023-8

\section{Submit your manuscript to a SpringerOpen ${ }^{\odot}$ journal and benefit from:}

- Convenient online submission

- Rigorous peer review

- Immediate publication on acceptance

- Open access: articles freely available online

- High visibility within the field

- Retaining the copyright to your article

Submit your next manuscript at springeropen.com 